for ethnic economies. The local ethnic economy is acknowledged as a stabilising factor in the neighbourhood. Local training alliances are able to help to create apprenticeship training positions in ethnic businesses. As migrants often have to rely on informal support networks and ethnic economies, some authors (Häussermann \& Siebel, 2001) propose that it would be necessary to reduce the intensity of formal controls in the economic sector. Immigrants have difficulties in accessing formal labour markets. As a result, ethnic economies often thrive in a sort of grey area of labour legislation and overly strict application of legal regulations could dry up these resources. Economy and labour law rules therefore need to be handled more pragmatically in the case of ethnic business.

Further important policy action areas lie in education and language acquisition, participation, neighbourhood security and architecture. Policy measures should encourage tenant's participation and self-organization in promoting campaigns for increased participation of immigrants. Measures in the form of low threshold events should be implemented which enable the local migrant population to make personal contacts and directly communicate with each other, thus involving them further in local initiatives.

A basic misunderstanding with this approach is that it would promote segregation, but the acceptance of the reality of ethnic colonies must not be interpreted as a retreat from political responsibility! In many European cities the fact is that the local policy accepts the results of segregation but the politicians do not discuss the topic in public due to their perception of political correctness. Immigration requires local policymakers to perform an extraordinarily difficult balancing act to both permit and prevent segregation, to accept immigrant neighbourhoods as a lasting institution of the city, to secure public spaces, and to establish conflict management mechanisms. There cannot be a simple solution for all these problems and thus, instead of trying to alter the spatial distribution of social problems, municipalities should try to solve social problems by targeting them directly with area-based initiatives in the respective quarters instead of fighting against segregation (see Münch, 2006).

\title{
7 Outlook
}

Housing is a crucial part of the integration process for residents with migratory backgrounds. Local housing policies have to deal with the specific housing situation of migrants, often within the scope of general housing policies for vulnerable groups. The supply and provision of access to affordable social housing seems to be a major method of ensuring decent housing for low income groups of migrants. The spatial concentration of social housing units is also an important aspect. The spread of social housing and small units of social housing across the city are highly relevant for the integration process of migrants allocated in social housing. However cities are also aware that some degree of concentration cannot be avoided. 
In general, a mix of different types of housing and different ethnic groups within the native population seems to be advisable. In addition, a balanced socio-economic (income groups) and demographic composition of the population is regarded as an important aspect of anti-segregation policy. Evaluating the segregation of migrants should be based on an analysis of the dynamics of this phenomenon. Certain segregated areas within a city may have a positive function for the integration of migrants if an outward mobility of residents of these areas exists and the cultural background of the residents in these areas is heterogeneous. Segregated neighbourhoods may also provide social support for newly arriving migrants.

In general, experience from existing policies show that integrated approaches which tackle a broad scope of dimensions simultaneously are more effectiveness than single issue policies. It should also be clear that all policies related to housing and segregation need a long term perspective.

\section{Bibliography}

Aarflot, U. (2001), Ethnic diversity in a deprived urban area - the allocation of asylum seekers in Sighhill, Glasgow, Term paper, Department of Geography, University of Bergen.

Abbas, T. (2002), Muslims in Birmingham, UK. Background Paper for COMPAS. (http://www.compas.ox.ac.uk/publications/papers/Birmingham\%20Background\%20Paper \%200206.pdf).

Allen, J. (2000), A southern way of housing? London: Westminster University, mimeo.

Allen, J., Barlow, J., Leal, J., Maloutas, T. \& L. Padovani (2004), Housing and welfare in Southern Europe. Oxford: Blackwell.

Alpheis, H. (1990), „Erschwert die ethnische Konzentration die Eingliederung?“،, in H. Esser \& J. Friedrichs (eds.) Generation und Identität. Theoretische und empirische Beiträge zur Migrationssoziologie, 209-237. Opladen: Westdeutscher Verlag.

Andersen, H. S. (2004), Residents' Understanding of Deprived Urban Neighbourhoods and its Significance for Plans to Move. Paper to ENHR conference 2004 in Cambridge, Workshop 29. Poverty Neighbourhoods (http://www.google.com/search?q=cache:A-wgZeXBXXoJ: www.sbi.dk/download/pdf/enhr_2004b.pdf+deprived+neighbourhoods).

Andersson, R. (1998), Segregation dynamics and urban policy issues in Sweden, Paper presented at the Metropolis Inter Conference on 'Divided cities and strategies for undivided cities', Göteborg, Sweden, 25-26 May 1998.

http://www.international.metropolis.net/events/goth/segregation.html.

Andersson, R. (2006), Breaking segregation' - rhetorical construct or effective policy? The case of the metropolitan development initiative in Sweden. Urban Studies 43, 4: 789-799.

Andersson, K. \& C. Blankenburg (CECODHAS, ed.) (2005), Integration through improved housing and empowerment. Conference Report, 14-15 April 2005. Stockholm.

Andrusz, G., Harloe, M. \& I. Szelenyi (eds) (1996), Cities after socialism: urban and regional change in post-socialist societies. London: Blackwell Publishers. 